\title{
NEW VARIETIES OF PLANTS AND LEGAL PROTECTION OF BREEDER'S RIGHT - THE UPOV CONVENTION AND ITS MAJOR ECONOMIC CONSEQUENCES
}

\author{
Uroš Ćemalović ${ }^{1}$, Milica Petrović ${ }^{2}$ \\ *Corresponding author E-mail: contact@uroscemalovic.com
}

\begin{tabular}{l} 
A R T I C L E I N F O \\
Review Article \\
Received: 03 December 2018 \\
Accepted: 05 May 2019 \\
doi:10.5937/ekoPolj1902513C \\
UDC 347.77[633/635:575 \\
\hline
\end{tabular}

Keywords:

breeder's right, intellectual property, new varieties of plants, UPOV Convention

JEL: K32, Q57

\begin{abstract}
A B S T R A C T
The International Convention for the Protection of New Varieties of Plants (UPOV Convention) represents the most comprehensive international legal mechanism in this field. In spite of the fact that the UPOV Convention introduces only certain minimal common rules regarding the so called breeder's right, the efficiency and the level of acceptance of the entire UPOV system have had numerous economic and social benefits: significant increase of productivity, transparent and just mechanism for rewarding scientific effort and investment in research, important incentive for international trade of new varieties of plants and undisputed impact on agricultural and horticultural development. This paper provides a targeted analysis of the important provisions of the UPOV convention (notion of breeder, grant of breeder's right and its content) and examines some of its major economic consequences. It argues that the UPOV convention remains an effective international legal mechanism for the protection of new varieties of plants.
\end{abstract}

(C) 2019 EA. All rights reserved.

\section{Introduction}

The introduction of new varieties of plants (including fruits and vegetables, but also other agricultural and ornamental plants) is beneficial from agricultural, economic and social point of view. As it was pertinently pointed out in theory, the benefits of new plant varieties include, but are not limited to "higher yield, resistance to pests and diseases, tolerance to stresses (...), greater efficiency in the use of inputs, improved harvestability and crop quality" (Sanderson, 2007). From an evolutionary perspective, the quintessence of breeding is "man's power of accumulative selection: nature gives successive variations;

1 Uroš Ćemalović, Ph.D., Research Associate, Institute of European Studies, Trg Nikole Pašića 11, 11000 Belgrade, Serbia; Phone: + 38163203 305, E-mail: contact@uroscemalovic.com, https://orcid.org/0000-0002-0760-9703.

2 Milica Petrović, LL.M. candidate, Graduate Student Instructor, Faculty of economy and judiciary, Mitropolita Petra 8, 11000 Belgrade, Serbia; Phone: +381 60367 1682; E-mail: milica3500@gmail.com, https://orcid.org/0000-0002-7528-7179. 
man adds them up in certain directions useful to him. In this sense he may be said to make for himself useful breeds" (Darwin, 1860). Without any pretention to minimize the importance of biological, botanic and other natural sciences-related aspects of breeding new varieties of plants, the main perspective of this paper will be legal-economic, while the new value created in the process of breeding will be seen as an intangible, intellectual creation and, consequently, the subject of intellectual property rights (IPRs). Seen under this angle, the process of breeding a new variety of plant (or discovering and developing an existing one) is very often a result of a serious scientific research, which, in principle, includes not only long-lasting effort of highly competent teams, but also important investments. On the international level, the first legal act that introduced a specific mechanism for the protection of breeders' rights was the International Convention for the Protection of New Varieties of Plants (known under the French acronym UPOV Convention) $)^{3}$, signed in December 1961 (came into force in August 1968). Half a century of its existence in the international legal system has brought up a creation of a new, specific IPR, with important economic and social consequences. This paper provides a targeted analysis of the UPOV convention (its legal specificity, global relevance, scope and the most important provisions) and examines some major economic consequences of the legal framework introduced by the UPOV convention.

\section{Materials and methodology}

Taking into consideration the object of the analysis (international normative framework and its enforcement), the content analysis and comparative legal method will be used as the main toll, completed with teleological analysis (normative framework) and impact assessment (economic outcomes). For the purposes of the analysis of the legal specificity, global relevance and scope of the UPOV Convention, data used originates from three major institutional sources (IUPNVP, AIPO, EU). As for the notion of breeder under the UPOV Convention, the possibilities of divergent interpretation have led to the semantic and teleological analysis of both French and English versions of Article 41. Regarding the grant of breeder's right and its content, due to the limited space, the content analysis will be reduced to Articles 5-9, 14, 15 and 20 of the UPOV Convention. Moreover, other non-binding acts will also be taken in account, such as explanatory notes (as referenced in respective chapters). The issue of balancing between public and private interests will not be examined in detail, given that, by its scope, it does not concern exclusively the new varieties of plants. Finally, the analysis of the economic outcomes of the UPOV Convention is based on data used originates from both independent and institutional sources, with a focus on multi-annual statistical overviews.

3 One of the main consequences of this Convention was the creation of so called International Union for the Protection of New Varieties of Plants or, in French, Union internationale pour la protection des obtentions végétales (UPOV). Besides its well-known (traditionally undoubted, but now somewhat fading) importance in international diplomatic and conventional relations, the reason why French acronym prevailed can be found in Art. 41 of the Convention, providing that ,This Convention shall be signed in a single original in the English, French and German languages, the French text prevailing in case of any discrepancy among the various texts". 


\section{Results and discussions}

The UPOV convention, as the most comprehensive international legal mechanism for the protection of new varieties of plants, introduces the minimal common rules regarding the conditions for the protection of breeders' rights and the prerogatives it implies. Moreover, the Convention establishes the International Union for the Protection of New Varieties of Plants (IUPNVP) and gives to the applicants for breeder's right certain important prerogatives, applicable in all other states signatories of the Convention. Therefore, besides its legal specificity, global relevance and scope, the issues to be addressed in the examination of the UPOV Convention are, on the one hand, the notion of the breeder and, on the other, the conditions for the grant of breeder's right and its content.

Given the specificity of the object of protected right, the legal mechanism for the protection of new varieties of plants, notwithstanding its important specificities, belongs to the multifaceted system of intellectual property rights. In other words, a new plant variety can theoretically also be an object of patent application, but different countries all over the world have had fundamentally different approaches concerning the patentability of plant varieties. For example, in 1980 the United States Supreme Court ruled that utility patents could apply to life forms, while, in Europe, the European Patent Office "has ruled that plant varieties are not patentable, although it has also held that transgenic methods and plants are not per se unpatentable (while) DNA sequences and aminoacid sequences corresponding to the peptides or proteins produced by a naturally occurring organism are unpatentable in a number of countries including Brazil, Cameroon, Colombia, Cuba, Guatemala and Uzbekistan" (Boettiger, Graff, Pardey, Van Dusen, Wright, 2004). Moreover, the development of international legal mechanisms aiming to guarantee an IPR-related protection of genetic resources is a sensitive and complex issues (Perdue, 2017). In any case, if one country allows both breeders' rights and patent protection for plants, such "overlaps in protection are resolved in the relevant jurisdiction, and not by UPOV" (Seville, 2016). However, demanding and long-lasting procedure for grant of a patent have additionally underlined the need for a specific mechanism for the legal protection of new varieties of plants, guaranteeing a reward for scientific effort and investment in research. The UPOV Convention was an adequate international response. As of October 13, 2017, the IUPNVP had 75 members, out of which 73 states, the African Intellectual Property Organisation (AIPO) and the European Union (EU). Both the AIPO and the EU operate "a plant breeders" rights system which covers the territory of 17 member States (for the AIPO) and 28 member States (for the EU). Consequently, the UPOV convention is applicable in 118 states and represents widely accepted and internationally relevant mechanism for the protection of new varieties of plants. Every member state of the IUPNVP disposes of a certain number of so called "contribution units", ranging from 0,2 (for the majority of members, including AIPO) to 5 (EU, France, Germany, Japan and the United States of America), while certain members have 0,25 (Brazil), 0,5 (Argentina, China, Czech Republic, Denmark, Hungary, Israel, Poland, Russian Federation, Slovakia and Turkey), 0,75 (Austria and Mexico), 1 (Australia, Canada, 
Finland, Ireland, New Zealand, Norway and South Africa), 1,5 (Belgium, South Korea, Sweden and Switzerland), 2 (Italy, Spain and United Kingdom) or 3 contribution units (Netherlands). In any case, two main features of the UPOV Convention are: 1) the introduction of common harmonised rules according to which its contracting parties "grant and protect breeders' rights" (Art. 2 of the UPOV Convention) and 2) the establishment of the IUPNVP, guaranteeing to the nationals or residents (for natural persons) of a contracting party - and to the registered offices (for legal entities) within the territory of a contracting party - prerogatives such as, for example, the national treatment or, for the applicants for the grant of breeder's right in one member state, 12 months lasting right of priority for any subsequent application concerning the same plant variety in all other member states of the IUPNVP.

For the good application of the UPOV Convention, it is essential to define the exact meaning of the notion of breeder. To do so, one should refer to both English and French versions of the Convention, not only because its Article 41 provides that "the French text (is) prevailing in case of any discrepancy among the various texts", but also given that the English version itself seems to encompass the two possible meanings of the notion of breeder. In Article 1 of the Convention, which provides the list of definitions "for the purposes of this Act", the "breeder" is defined as: 1) "person who bred, or discovered and developed, a variety" or 2) "the person who is the employer of the aforementioned person or who has commissioned the latter's work, where the laws of the relevant Contracting Party so provide", or 3) "the successor in title of the first or second aforementioned person, as the case may be". Given that the second and the third elements do not give rise to any interrogations regarding the notion of breeder (core element of the definition), here the focus will be on the first, crucial element of the definition. Moreover, adequate and stable definition of what the UPOV Convention understands under the notion of "breeder" also makes possible to define the person who is either breeder's employer, the person who has commissioned the breeder's work, or successor in title "of the first or second aforementioned person".

Textual and logical analysis of the core element of the definition indicates that the English version of the UPOV Convention implies the existence of both narrow and broad meaning of the word "breeder". In the narrow meaning, a breeder is the person who bred a (new) plant variety, while in the broad meaning, a breeder can also be the person who discovered and developed a plant variety, provided that the conditions related to discovering and developing should be fulfilled cumulatively. At this stage, referring to the French version of the Convention can be useful for better understanding of the notion of breeder. For the broad meaning of this notion, the French text uses the word obtenteur, which can literally be translated as "the one who obtained", notion that - notwithstanding the possibility of legitimate criticism from the semantic point of view - elegantly encompasses the two possibilities: obtenteur is both a person who 1) bred or 2) discovered and developed a variety. On the other hand, for the narrow meaning of the notion of breeder - which, in English version, derives from the participle (bred) of the verb 'to breed' - the equivalent French word would be 
créateur, given that the French text, in the place where the English version uses the word 'bred', employs the word créé. Consequently, the use of French version of the UPOV Convention translated into English would lead to the following definition: the person who "obtained" a plant variety is either the one who "created" a new variety, or the one who discovered and developed an existing ${ }^{4}$ one. In other words, "the discoverer of a new plant variety growing in the wild does not qualify the person as the 'creator' of new plant variety (given that) discovery alone is not enough to warrant protection under UPOV" (Sanderson, 2017), because "a breeder is more than a mere introducer of a discovered plant variety" (Lightbourne, 2016). A discoverer can only be considered as breeder in the broad sense if the discovery is accompanied with certain intellectual (scientific) effort that has led to the development of such plant variety. A contrario, a person who actually obtained a new plant variety - which can be done "through changing the deoxyribonucleic acid (DNA) of a plant via mutations" (Sanderson, 2017) - is a breeder in the narrow sense, given that the work of such a person led to the creation of a variety that can be maintained". In any case, "it bears noting that, like patents, the UPOV conventions have no global or absolute standard for determining novelty" (Mgbeoji, 2006). At this point, the issue of the notion of breeder meets another important matter - conditions the UPOV Convention requires for the grant of breeder's right and the content of this right.

The entire Chapter III (Articles 5-9) of the UPOV Convention is dedicated to the conditions to be fulfilled in order to grant breeder's right. All the four explicit conditions are related to the variety itself, which should be 1) new, 2) distinct, 3) uniform and 4) stable. In spite of the fact that Article 5-2 provided that "the grant of the breeder's right shall not be subject to any further or different conditions", the wording of this provision indicates the existence of the other three conditions. Primo, the variety should be "designated by a denomination" according to strict and detailed rules established by Article 20 of the UPOV Convention (including, for example: characteristics of the denomination, its registration, prior rights of third persons, rules related to information among the authorities of contracting parties, obligation to use the denomination, indications used in association with denominations). Concerning the principles for variety denomination defined by the UPOV Convention, they "were to a large extent informed by the existing principles and practices in botany, horticulture and taxonomy, (while) the underlying principles of all of the rules around variety denomination are to ensure that plant names are freely available for use and not confusing" (Sanderson, 2017). Secundo, the applicant for breeder's right should comply "with the formalities provided for by the law of the Contracting Party with whose authority the application

4 It should be noted that the novelty, for the purposes of the UPOV Convention, entirely depends on the commercialisation and does not require the absolute uniqueness or originality.

5 According to Art. 22-1(b)(i) of the UPOV Convention, ,each Contracting Party may cancel a breeder's right granted by it if, after being requested to do so and within a prescribed period, (i) the breeder does not provide the authority with the information, documents or material deemed necessary for verifying the maintenance of the variety." 
has been filed" (Art. 5-2 of the UPOV Convention). These formalities certainly cannot be considered as "conditions of protection" stricto sensu - and, consequently, should not influence the interpretation of the four explicit conditions - but without their fulfilment the right would not be granted. Tertio, the applicant should pay "the required fees" (Art. 5-2 of the UPOV Convention). Concerning the formalities required by the authorities of each contracting party to the UPOV Convention, the internal national legal or administrative rules cannot impose to the nationals (or registered legal entitles) of other parties the conditions and/or additional requirements that are not applicable to their own nationals or legal entities (the principle of national treatment). Given that a more detailed inquiry of the conditions for the grant of the breeder's right related to the distinctness, uniformity and stability would demand significant extra-legal escapades, here the focus will be on the novelty of a variety.

Besides the intangible nature of the object of the protection, one of the most significant similarities of breeder's rights and some other IPRs are the conditions for the grant of the right. However, even if the patent law also requires that a patentable invention must show an element of novelty, the novelty criterion for plant breeders' rights is significantly different, because "under UPOV it is defined in connection with the commercialisation of a plant variety, (while) the distinctiveness criterion (under UPOV) is fairly similar to the novelty criterion of patent law, since it requires that the protected variety must be clearly distinguishable from any other variety whose existence is a matter of common knowledge at the time of filing the application" (Kiene, 2011). More precisely, the commercialisationrelated novelty required by the UPOV Convention, besides the general rule demanding that "propagating or harvested material of the variety has not been sold or otherwise disposed of to others, by or with the consent of the breeder, for purposes of exploitation of the variety" (Art. 6-1 of the UPOV Convention), has two time and territory-related conditions: 1 ) in the territory of the country of filing the application - that the material of the variety has not been "sold or otherwise disposed of" earlier than one year counting from the day of application and 2) in the territory of all other contracting parties - that the same material has not been "sold or otherwise disposed of" earlier than four years (six years in the case of trees and vines) before the same date. It is particularly important to underline that the two aforementioned conditions are cumulative. In order to make easier the application and interpretation of the rules related to the novelty of plant variety, in August 2009, the office of the IUPNVP has issued the Explanatory Notes on Novelty Under the UPOV Convention. Besides presenting the evolution of the provisions of the UPOV Convention dedicated to novelty, this document brings an indicative list of acts which "may be considered not to result in the loss of novelty", like, for example: trials of the variety not involving sale or disposal of to others, sale or disposal of to others without the consent of the breeder or the same sale or disposal that forms part of an agreement transferring rights to the successor in title.

The UPOV Convention belongs to the complex set of rules for international IPR protection and, consequently, the breeder's right has important similarities with other IPRs. The right guaranteed to the breeder who has successfully fulfilled the conditions 
detailed in the last section is, basically, a time-limited exclusive right (legally guaranteed monopoly). This exclusive right is granted because the breeder should be rewarded for his intellectual and any other effort and investment, while the entire business community has to be motivated to invest in research and creating new (or developing existing) plant varieties. On the other hand, the public interest is protected by the fact that breeder's rights are limited in time. In other words, "any policy involving the protection of IPRs has to balance two sets of competing interest: the public interest in immediate and widespread dissemination (...) and the private interest of individual creators, seeking maximum opportunity to earn returns from their inventions" (Brossard, Shanahan, Nesbitt, 2007). In any case, breeder's exclusive right - very much alike numerous other IPRs - comprises two general prerogatives: 1) to exploit independently her/his right during the period of its registration (which cannot be shorter than 20 years) and 2) to (dis)allow to others certain acts of economic exploitation of her/his right. Article 14 of the UPOV Convention comprises a list of acts "in respect of the propagating material of the protected variety" that require the authorization of the breeder. Without entering in a more detailed analysis of these acts, it should be noted that they include, among others, production or reproduction, offering for sale, selling or other marketing, exporting and importing. There are also certain exceptions to the breeder's right, covering, for example, the acts "done privately and for non-commercial purposes" (Art. 15-1-i of the UPOV Convention) and "acts done for experimental purposes" (Art. 15-1-ii of the UPOV Convention). This and above-mentioned exceptions are compulsory, given that every contracting party should introduce them in their national legal systems. The same Article also comprises a third compulsory exception: "acts done for the purpose of breeding other varieties" and, with certain exceptions, "other acts in respect of such other varieties". The UPOV Convention also allows to the contracting parties to introduce some other (optional) exceptions, "in order to permit farmers to use for propagating purposes, on their own holdings, the product of the harvest which they have obtained by planting, on their own holdings, the protected variety" (Art. 15-2). In any event, after the expiration of breeder's right, the plant variety that used to be covered by breeder's exclusive right falls into the public domain and can be freely exploited. The balancing between, on the one hand, the private interest of the breeder to exploit as long as possible the variety he/she bred (or discovered and developed) and, on the other hand, the public interest to have permanent, free and unlimited access to plant varieties, is not always easy to find.

In spite of the fact that the UPOV system has been accused of "lacking transparency, being unaccountable and misusing its influence" (Sanderson, 2017), there is a broad consensus among researchers and in theory that a functional system for the protection of plant breeder's rights can significantly contribute to the economic growth and incentivize "plant breeding research by increasing returns on investments" (Prifti, 2015). In a more general context, legally guaranteed rights on new plant varieties - as it is the case of many other IPRs - tend to be "central to the innovation that drives economic growth" (Rimmer, 2011). Some recent studies have shown that the overall 
impact of the implementation of breeder's rights in a developing country, such as Vietnam, have had an undoubted positive implications, given that "the total sectoral income increase offered by plant breeding successes for major arable crops since the UPOV membership amounts to more than USD 2.3 billion (and) the yearly income of Vietnamese farmers has increased by over 24 percent since 2006" (Noleppa, 2017). In the same vein, the another example of an emerging economic power confirms the same conclusion: the legislative and regulatory changes introduced after Brazil became a member of the International Union for the Protection of New Varieties of Plants (May 1999) contributed to the increase of competition between breeders and the productivity of soya bean over a less than decade increased from $2.200 \mathrm{~kg} / \mathrm{ha}$ to 3.300 $\mathrm{kg} / \mathrm{ha}$ (Stroschon, 2012).

It is self-evident that the entire international legal framework dedicated to the protection of new varieties of plants is particularly beneficial for countries (or regions) with developed scientific, research and economic potentials. Moreover, the countries that allow dual protection of plant varieties by both patent law and UPOV-based breeder's right are, most often, those who are economically well developed, offering to their researchers to use a heavy-weight patent protection, leaving "virtually no exception for farmers and plant breeders" (Ravi Srinivas, 2015). On the other hand, there is no significant discord among researchers (Vaver, 2006) that the UPOV Convention, as a set of minimal common international legal rules for the protection of breeders' rights, contributes to the increase of productivity and can incentivise the international trade of new varieties of plants (Phillips, Khachatourians, 2001). However, "in light of effective international solutions being slow to eventuate" (Butterfield, 2018), the important positive economic effects are still to be expected. Concerning the possible increase in the price of seed, experts from developing countries pointed out that it "has been normally defended by the argument that the increase is offset by the advantages the farmer would reap because of the increased productivity of the new varieties (given that) the profits to the farmer would outweigh the cost due to the propensity of the private sector to release new varieties" (Prasad, 1995). It, however, remains to establish if and to which extent the UPOV system contributes to better economic results of small and medium plant growers and farmers from developing countries. Not only productivity itself, but also numerous other aspects related to the crops can considered as relevant from producers' point of view; according to some, these are growing cycle, disease resistance and ease of husbandry (Stroschon, 2012).

The positive economic effects of the entire set of breeders' rights largely depends on the functional system of compensation in the case of violation of the prerogatives of the rightful holder of plant variety protection. The UPOV Convention itself does not procure any specific provisions regarding liability, damage compensation or any other rule allowing to determine the procedure applicable when a violation of breeder's right requires legal mechanisms in order to recompense every real or potential damage caused to breeder's interests and prerogatives. In the absence of internationally accepted legal mechanisms, all member states to the UPOV Convention are free - provided that 
they do not violate other provisions of the Convention - to set up their own national rules for damage compensation. In numerous countries, the general rules on civil liability and damage compensation are also applicable in case of violation of breeder's right. Moreover, given that the rights covering new varieties of plants belong to the more general set on national and international legislation on IPR protection, damage compensation applicable in case of violation of some other IP-related rights can, mutatis mutandis, be applied to liability for plant breeder's right infringement. What particularly counts here is the intangible nature of the object of IPR and the existence of two specific types of undue exercise of an IPR that could lead to infringement: "act of denigration that requires an alleged infringement to be circulated to third parties" (Heath, 2007) and the undue exercise of an IPR "as such (...) as an act of unduly interfering with a competitor's business" (Heath, 2007). Applied to plant breeder's right, both the possibility of unlawful circulation to the others and of undue interfering are not only theoretically possible, but also present in practice. In any case, there is a broad consensus in theory that "climate change will increase the importance of new plant varieties that can adapt to changing climatic conditions" (Condon, Sinha, 2013). In such a context, the economic importance of the development on new plant varieties and of the adequate legal protection in case of violation of breeder's rights can hardly be overestimated.

One of the best ways to estimate the real economic impact of the legal framework set by the UPOV Convention is the analysis of the number of applications and titles granted, especially when done in comparison with another internationally recognised mechanism, such as the one existing within the European Union. EU's Community plant variety office (CPVO), according to its annual report for 2017, have received 3.422 applications, which represents a significant increase when compared to last year's results. In percentage, this increase of 3,7\% represents the second highest number in received applications during past six years. Nevertheless, there have been some minor changes when it comes to the number of applications per crop sector. In 2017, the highest increase was registered in fruit sector (69 applications) and ornamental sector (233 applications), while the situation is quite different in other sectors, such as vegetable sector or agricultural sector, in which the number of applications is decreasing. Moreover, the most active applicants are the entities from EU member states. The Netherlands have taken the first place, by sending more than 1.352 applications, which makes one third of all the applications received. As for the countries outside the EU, the highest number of applications came from the United States (265) and Switzerland (149). This is due to the fact that applicants outside the EU have to have a representative registered in the Union, which can be done either by forming a daughter company or by taking an external agent. As for the number of guaranteed rights, it has grown up to 2.865. This result shows the second highest number ever guaranteed by the CPVO during one year. According to the CPVO's official data, out of 47.638 rights guaranteed, 25.913 are still in force $(54,4 \%$ of initially granted rights). 
Table 1. Number of applications and titles granted by the CPVO

\begin{tabular}{|l|l|l|}
\hline Year & $\begin{array}{l}\text { Number of } \\
\text { applications }\end{array}$ & $\begin{array}{l}\text { Number of titles } \\
\text { granted }\end{array}$ \\
\hline 2013 & 3.297 & 2.706 \\
\hline 2014 & 3.626 & 2.684 \\
\hline 2015 & 3.111 & 2.844 \\
\hline 2016 & 3.299 & 2.980 \\
\hline 2017 & 3.422 & 2.865 \\
\hline
\end{tabular}

Source: Community plant variety office, Annual report for 2017

When it comes to the similar statistical parameters within the UPOV system, the analysis of the Plant variety protection statistics for the period 2013-2017 shows that, in year 2017, the number of received applications was at its highest with 18.306 applications, out of which 12.685 were successful, which is the increase of about $18 \%$ in the number of given titles when compared to year 2013 .

Table 2. Number of applications and titles granted in the UPOV system

\begin{tabular}{|l|l|l|}
\hline Year & $\begin{array}{l}\text { Number of } \\
\text { applications }\end{array}$ & $\begin{array}{l}\text { Number of titles } \\
\text { granted }\end{array}$ \\
\hline 2013 & 17.788 & 10.052 \\
\hline 2014 & 15.511 & 11.566 \\
\hline 2015 & 15.017 & 12.409 \\
\hline 2016 & 16.455 & 12.550 \\
\hline 2017 & 18.306 & 12.685 \\
\hline
\end{tabular}

Source: International Union for the Protection of New Varieties of Plants, Plant variety protection statistics for the period 2013-2017 - revision

The comparative analysis of data regarding both UPOV and CPVO clearly indicates that, in spite of the setback over relatively short period of time (for the CPVO year 2015 and, to some extent, 2016; for the UPOV, the period 2014-2016) the number of applications and titles granted increases again from 2016. However, only within the UPOV system, the results for year 2017 are better than those for year 2013, both in terms of number of applications and granted rights.

\section{Conclusions}

The International Convention for the Protection of New Varieties of Plants (UPOV Convention) is a widely accepted international legal mechanism for the protection of the rights of persons who either bred a (new) plant variety or who discovered and developed an (existing) one. Its two main features are, on the one hand, the introduction of the minimal common rules regarding the conditions for the protection of breeders' rights (harmonisation of national legislations) and, on the other, the creation of the International Union for the Protection of New Varieties of Plants, providing to the applicants for breeder's right certain important prerogatives, applicable in all other signatories of the Convention. Concerning the harmonisation of national legislations 
introduced by the UPOV Convention, particularly worth mentioning are the provisions of the Convention dedicated to the notion of breeder, the grant of breeder's right and the content of such right. The progressive harmonisation of national legislations have certainly had positive economic effect, contributing to the better conditions for more substantial international trade. However - as it is the case of many other intellectual property rights - the added value and real economic impact of the UPOV Convention still critically depends on the efficient national legal mechanisms for its enforcement.

\section{Conflict of interests}

The authors declare no conflict of interest.

\section{References}

1. Boettiger S., Graff G., Pardey P., Van Dusen E., Wright, B. (2004). Intellectual Property Rights for Plant Biotechnology: International Aspects, in: Christou P. and Klee, H. (Eds.), "Handbook of Plant Biotechnology", John Wiley \& Sons, Ltd., Chichester, 1089-1113.

2. Butterfield, B. (2018). "The potential role of climate change litigation in furthering the mitigation objectives of the Paris Agreement", Asia Pacific Journal of Environmental Law 1-2018, Edward Elgar Publishing, 29-49.

3. Brossard, D., Shanahan J., Nesbitt T. (2009). The Media, the Public and Agricultural Biotechnology. Seeds of Change. Ed. Jay Kesan - CABI, Oxfordshire.

4. Christou, P. and Harry Klee, H. (Eds.) (2004). Handbook of Plant Biotechnology. John Wiley \& Sons, Ltd., Chichester.

5. Condon, B., Sinha, T. (2013). The Role of Climate Change in Global Economic Governance. Oxford University Press, Oxford.

6. Darwin, C. (1860). Origin of Species, $2^{\text {nd }}$ British edition, London.

7. Heath, C. (2007). The interface between competition law and intellectual property in Japan, in: Anderman S. (Ed.), "The Interface Between Intellectual Property Rights and Competition Policy", Cambridge University Press, Cambridge, 250-311.

8. Kiene, T. (2011). The Legal Protection of Traditional Knowledge in the Pharmaceutical Field. Waxmann Verlag, Münster.

9. Lightbourne. M. (2016). Food Security, Biological Diversity and Intellectual Property Rights. Routledge, Oxon.

10. Matthews, Duncan and Zech, Herbert (Eds.) (2017). Research Handbook on Intellectual Property and the Life Sciences. Edward Elgar, Cheltenham.

11. Mgbeoji, I. (2006). Global Biopiracy: Patents, Plants, and Indigenous Knowledge. UBC Press, Vancouver.

12. Noleppa, S. (2017). The socio-economic benefits of UPOV membership in Viet Nam: An ex-post assessment on plant breeding and agricultural productivity after ten years (Executive Summary), HFFA Research Paper 03/2017, Berlin. 
13. Perdue, D. (2017). "Patent Disclosure Requirements Related to Genetic Resources: The Right Tool for the Job?", Biotechnology Law Report 6-2017, Mary Ann Liebert, New York, 285-296.

14. Phillips, P., Khachatourians, G. (2001). The Biotechnology Revolution in Global Agriculture: Innovation, Invention and Investment in Canola Industry. CABI Publishing, Oxon.

15. Prasad, J. (1995). Dunkel Proposals and Indian Agriculture, in: Krg Nair, Ashok Kumar (Eds.), "Intellectual Property Rights", Allied Publishers Limited, New Delhi.

16. Prifti, V. (2015). The Breeder's Exception to Patent Rights - Analysis of Compliance with Article 30 of the TRIPS Agreement. Springier, Heidelberg.

17. Ravi Srinivas, K. (2015). Intellectual Property Rights and the Politics of Food, in: Ronald Herring (ed), "The Oxford Handbook of Food, Politics, and Society", Oxford University Press, Oxford

18. Rimmer, M. (2011). Intellectual Property and Climate Change - Inventing Clean Technologies. Edward Elgar, Cheltenham.

19. Sanderson, J. (2017). Plants, People and Practices - the Nature and History of the UPOV Convention. Cambridge University Press, Cambridge.

20. Seville, C. (2016). EU Intellectual Property Law and Policy. 2nd edition, Edward Elgar, Cheltenham.

21. Stroschon, O. (2012). The use of plant variety protection to add value for farmers in Brazil in: "Proceedings of the Symposium on the Benefits of Plant Variety Protection for Farmers and Growers", November 2012, Geneva.

22. Vaver, D. (2006). Intellectual Property Rights: Critical Concepts in Law. Routledge, London.

23. Annual report for 2017, Community plant variety office, Retrieved from https:// cpvo.europa.eu/sites/default/files/documents/cpvo_annual_report_2017.pdf (October 20, 2018)

24. Planet variety protection statistics for the period 2013-2017 (r), Retrieved from https://www.upov.int/meetings/en/doc_details.jsp?meeting_id=48108\&doc_ $\mathrm{id}=419517$ (October 26, 2018)

25. Explanatory Notes on Novelty Under the UPOV Convention, Retrieved from http:// www.upov.int/edocs/mdocs/upov/en/c/43/upov_exn_nov_draft_3.pdf (November 13, 2018)

26. Proceedings of the Symposium on the Benefits of Plant Variety Protection for Farmers and Growers, Retrieved from http://www.upov.int/edocs/pubdocs/en/ upov_pub_357_4.pdf(November 20, 2018) 